\title{
Analysis of administrative barriers in the industry of the high-rise construction in Russian Federation
}

\author{
Irina Zaychenko ${ }^{1}$, Alexandra Borremans $^{1 *}$ and Svetlana Gutman ${ }^{1}$ \\ ${ }^{1}$ Peter the Great St. Petersburg Polytechnic University, Institute of Industrial management, Economy \\ and Trade, 195251, Polytechnicheskaya, 29, St.Petersburg, Russia
}

\begin{abstract}
The article describes the concept and types of administrative barriers encountered in various areas of the enterprise. The particularities of the Russian high-rise construction industry are described and a comparative analysis of administrative barriers in this sector is performed. The main stages and administrative procedures when the developers implement investment and construction projects in the field of high-rise construction are determined. The regulatory and legal framework for the implementation of investment and project activities in the high-rise construction industry has been studied and conclusions have been drawn on its low level of precision in the issue of the formation of competitive and efficient high-rise construction markets. The average number of administrative procedures for the implementation of the investment and construction project in the field of high-rise construction is determined. The factors preventing the reduction of administrative barriers in the high-rise construction industry are revealed.
\end{abstract}

\section{Introduction}

Administrative barriers in construction are one of the most significant problems of the industry. Because of these issues the problems inherent in the Russian construction market are constantly self-reproducing: monopolization, corruption and as the result of such conditions the ineffectiveness of the market mechanism. Construction organizations face insurmountable administrative obstacles that may adversely affect the socially important task - the realization of affordable and comfortable housing for Russian citizens.

The relevance of this study is determined by the need to improve the efficiency of realization of investment and construction projects in the field of high-rise construction by optimizing administrative procedures [1]. It is necessary to develop and implement new measures to reduce administrative barriers in high-rise construction.

The aim of the work is to analyze the administrative barriers in the high-rise building industry and to identify the problems that arise when eliminating them.

\footnotetext{
* Corresponding author: alexandra.borremans@mail.ru
} 


\section{Materials and Methods}

The construction sector, and in particular the high-rise construction sector, is the object of close attention of public authorities. This is primarily due to the need of addressing at the state level such issue as the turnover of land, preserving the architectural and functional integrity of the urban infrastructure and the technical safety of the constructed facilities.

However, excessive state regulation of the sector can lead to a business activity restriction of organizations, and the availability of an administrative resource can promote the monopolization of the construction market. According to different estimates, the GDP losses caused by the overestimated construction cost due to competition restrictions in this sector are annually from $0.21 \%$ to $0.54 \%$ [2].

Moreover, it can be assumed that administrative barriers restrain the development of competition in the industry, reduce the employment of the population, increase the corruption of business conditions, increase the cost and time required to complete a concrete transaction. Weak competition in the construction market hinders the development of this sector, blocks the improvement of construction quality, and also leads to an overestimated cost per square meter of housing, resulting in its low availability for the population. The reasons for weak competition in the construction sector, nevertheless, are linked not only to the policy of constructors, but also to the situation in the related markets and the presence of an excessive number of administrative barriers.

Administrative barriers are the rules established by decisions of state and municipal authorities, observance of which is a prerequisite for business in the area, which significantly increases the cost and time of passing bureaucratic procedures.

The analysis of previous researches by types of administrative barriers [3-6], allows making the following classification, presented in tab. 1.

Table 1. Classification of administrative barriers.

\begin{tabular}{|c|c|}
\hline $\begin{array}{c}\text { Scope of the administrative } \\
\text { barrier }\end{array}$ & Barrier type \\
\hline $\begin{array}{c}\text { Obtaining the right to conduct } \\
\text { business }\end{array}$ & Company registration \\
\hline & Agreement of project documentation with government \\
agencies
\end{tabular}




\begin{tabular}{|c|c|}
\hline & Inspection activity of authorized government agencies \\
\hline & $\begin{array}{c}\text { Introduction of norms of mandatory approvals and } \\
\text { registrations of decisions by government agencies }\end{array}$ \\
\hline $\begin{array}{c}\text { Administrative barriers of a } \\
\text { general nature }\end{array}$ & Contradiction of current legislation \\
\hline & Imperfection of the current legislation \\
\hline & Violation of legal guarantees for business entities \\
\hline
\end{tabular}

These types of administrative barriers are common. However, as mentioned above, entrepreneurial activities within the urban development sector are the most susceptible to the influence of administrative barriers. Thus, $74 \%$ of surveyed construction companies assess the administrative barriers in the market as "high" or "prohibitively high" [7].

In addition, the level of administrative barriers in the largest Russian cities varies significantly. In Moscow, for example, the number of all reconciliation procedures averages 54 , takes 704 days and $2612.8 \%$ of per capita income, while, for example, in Rostov-on-Don, only 22 procedures need to be completed, spending 194 days and $272.9 \%$ of per capita income [8]. For business related to high-rise construction, such regional differences in the difficulty of obtaining approvals and permits for construction in the implementation of investment projects are one of the determining factors when choosing an object for investment.

High entry barriers to local high-rise markets limit the access of constructors to such markets, which leads to monopolization of the industry. Imperfect competition in the markets significantly limits the potential for increasing the volume of high-rise construction and, ultimately, leads to a reduction in the affordability of housing for the population.

Analysis of the regulatory framework [9-12] shows that there is formally a certain legal and regulatory framework for the implementation of investment and project activities in the high-rise construction industry, but in practice this is not applied. There is no institutional environment conducive to the formation of competitive and efficient markets for high-rise construction. The main reason for this is the presence of redundant administrative barriers, namely, numerous conciliation and licensing procedures that are mandatory for the developer in the implementation of the investment and construction project.

In order to identify administrative barriers in the high-rise construction industry, the main stages and main administrative procedures of investment and construction projects implementation in this area by developers were determined. Thus, when implementing an investment and construction project in the field of high-rise construction, it is common to distinguish five main stages [13]:

1. Land-building and urban planning.

2. Preparation of project documentation.

3. Construction.

4. Commissioning of the facility.

5. State cadastral registration and state registration.

The tab. 2 presents the main administrative barriers at each of these stages.

Table 2. Problems in the passage of administrative procedures at each stage of the investment and construction project in the field of housing construction.

\begin{tabular}{|c|c|}
\hline $\begin{array}{c}\text { Stage of the investment } \\
\text { and construction project } \\
\text { in the field of high-rise } \\
\text { construction }\end{array}$ & Issues in passing administrative procedures \\
\hline
\end{tabular}




\begin{tabular}{|c|c|}
\hline \multirow{3}{*}{$\begin{array}{l}\text { Land-building and urban } \\
\text { planning }\end{array}$} & Issues associated with obtaining a town planning plan for a land plot. \\
\hline & $\begin{array}{l}\text { Issues associated with obtaining technical conditions for connection } \\
\text { to networks of engineering infrastructure. }\end{array}$ \\
\hline & $\begin{array}{l}\text { Issues associated with the holding of auctions for the provision of } \\
\text { land for housing construction. }\end{array}$ \\
\hline \multirow{4}{*}{$\begin{array}{l}\text { Preparation of project } \\
\text { documentation }\end{array}$} & $\begin{array}{c}\text { Duration and high cost of passing the state expertise of project } \\
\text { documentation and engineering survey results. }\end{array}$ \\
\hline & $\begin{array}{l}\text { A large number of approvals of project documentation in local } \\
\text { government agencies, city services, organizations operating } \\
\text { engineering and maintenance networks. }\end{array}$ \\
\hline & High cost of connection to the networks of engineering support. \\
\hline & Lack of qualified personnel in the design. \\
\hline \multirow{3}{*}{ Construction } & The length of time for obtaining a building permit. \\
\hline & The length of time for obtaining a warrant for earthworks. \\
\hline & $\begin{array}{l}\text { A large number of inspections by state construction supervision } \\
\text { agencies. }\end{array}$ \\
\hline \multirow{5}{*}{ Commissioning } & $\begin{array}{l}\text { Long terms of Rostekhnadzor (the Federal Service for Ecological, } \\
\text { Technological and Nuclear Supervision) procedures for } \\
\text { commissioning the facility. }\end{array}$ \\
\hline & $\begin{array}{l}\text { Long time for obtaining permission to put the facility into } \\
\text { exploitation. }\end{array}$ \\
\hline & $\begin{array}{l}\text { A large number of approvals with organizations operating } \\
\text { engineering and technical support networks and other organizations } \\
\text { necessary to obtain a permit to put the facility into exploitation. }\end{array}$ \\
\hline & $\begin{array}{l}\text { The requirement to conclude contracts for connection to the } \\
\text { engineering support network in the number of documents required to } \\
\text { obtain a permit for commissioning the facility. }\end{array}$ \\
\hline & $\begin{array}{l}\text { Double technical inventory of the object - before and after putting } \\
\text { the facility into exploitation. }\end{array}$ \\
\hline $\begin{array}{l}\text { State cadastral registration } \\
\text { and state registration of } \\
\text { rights }\end{array}$ & Long term registration of ownership of real estate. \\
\hline
\end{tabular}

Thereby, the main administrative barriers in the high-rise construction industry are: excessive number of administrative procedures; long terms of passage of administrative procedures; high cost of passing administrative procedures.

For realization of the investment and construction project in the field of high-rise construction, the developer needs a certain regulation that would reflect administrative procedures step-by-step, which he must pass with a mandatory indication of the time, amount and cost. Nowadays, the industry has not established a clear, transparent regulation with an established list of administrative procedures for the developer to implement the investment and construction project in the field of housing construction, which strongly provokes the problem of excessive administrative barriers.

At the stage of land management and town planning training, if the right to land is not obtained by the developer at the auction, it is necessary to pass about 2 times more procedures than foreign practices [14]. In this case, if it is necessary to change the permitted type of land plot use, this requires especially a lot of time - an average of 229 days [8].

One of the most common ways to obtain the right to a land plot is to acquire a property right or lease a land plot at an auction. In this case, the period of passing the procedures at the stage of land management and urban planning is almost halved (to 136 days). At the same time experts pointed out such problems as the absence or a small number of auctions for the provision of land for housing construction, the lack of information on the conduct of such auctions, the high price of land, a small number of land plots. A serious problem in the 
administrative procedures at the stage of land management and urban planning in many cities is the long period of obtaining a town-planning plan for a land plot. For instant, it is on average 54 days in case of obtaining rights to a land plot at auction and 166 days in case the developer has rights to a land plot, received not at auction. This is related also with the fact that the developer must first obtain technical conditions for connecting to the networks of engineering and technical services [15].

At the design stage, one of the main problems is a large number of approvals for project documentation in local government agencies, city services and organizations operating engineering and technical support networks - on average, 18 procedures are required, spending an average of 144 days on this. At the same time, in some cities the number of procedures at the design stage reaches 26 . It is important to note that the federal legislation on urban development does not require any coordination of project documentation, except for state expertise. Unjustifiably long and expensive are the procedures associated with the passage of state expertise of project documentation and engineering survey results, requiring an average of 66 days and 711 thousand rubles. The cost of connection to the networks of engineering and technical support and the coordination of technical connection conditions at this stage (on average 20 million rubles) are also estimated as high.

During the construction phase, as the main problems, experts noted the long terms of obtaining a building permit and a large number of inspections by state construction supervision authorities. For the passage of procedures related to obtaining a building permit and other documents required for construction work at this stage, an average of 140 days is required. In the process of construction, on average, 11 inspections should be conducted by the state construction supervision authorities. However, their number can reach 43 . It should be noted that the total number and regularity of inspections of construction by state construction supervision authorities in federal legislation are not defined.

The stage of commissioning the facility is the third in terms of the duration of the passage of all administrative procedures in the process of realization an investment and construction project in the field of housing construction. On average, at this stage it is necessary to pass 35 procedures and spend 189 days, $70 \%$ of this time is required for passing procedures related to the confirmation of the readiness for operation of public utility systems and the conclusion of contracts for resource supply, which is a significant problem in the process of implementing the construction project. Passage of administrative procedures at this stage is estimated at an average of 621 thousand rubles. Averages of $86 \%$ are the costs associated with the procedures for confirming the readiness for the operation of public service systems and with the conclusion of contracts for resource supply.

At the stage of state cadastral registration and state registration of property rights for real estate, the main problem is a long period of state registration. At this stage, it is necessary to undergo an average of 3 procedures, the total average cost of which is 3090 thousand rubles. The passage of administrative procedures at this stage of the project takes an average of 59 days; however, in some cities it reaches 120 days. The procedure for registering ownership of real estate is regulated by federal legislation and is carried out by the territorial bodies of the Federal Service for State Registration, Cadastre and Cartography. The duration of this procedure is from 3 to 60 days - whereas on average it takes 23 days.

Fig. 1 shows the cumulative average number of procedures for the implementation of investment and construction project in the field of high-rise construction in the following options:

- Obtaining ownership rights to a land plot or the right to conclude a lease contract for a land plot at an auction (Option 1);

- The land plot is owned or leased from the developer for other reasons and does not require a change in the permitted type of use (Option 2 without considering the change in the permitted use); 
- The land plot is owned or leased from the developer for other reasons and requires a change in the permitted type of use (Option 2, taking into account the registration of the permitted type of use).

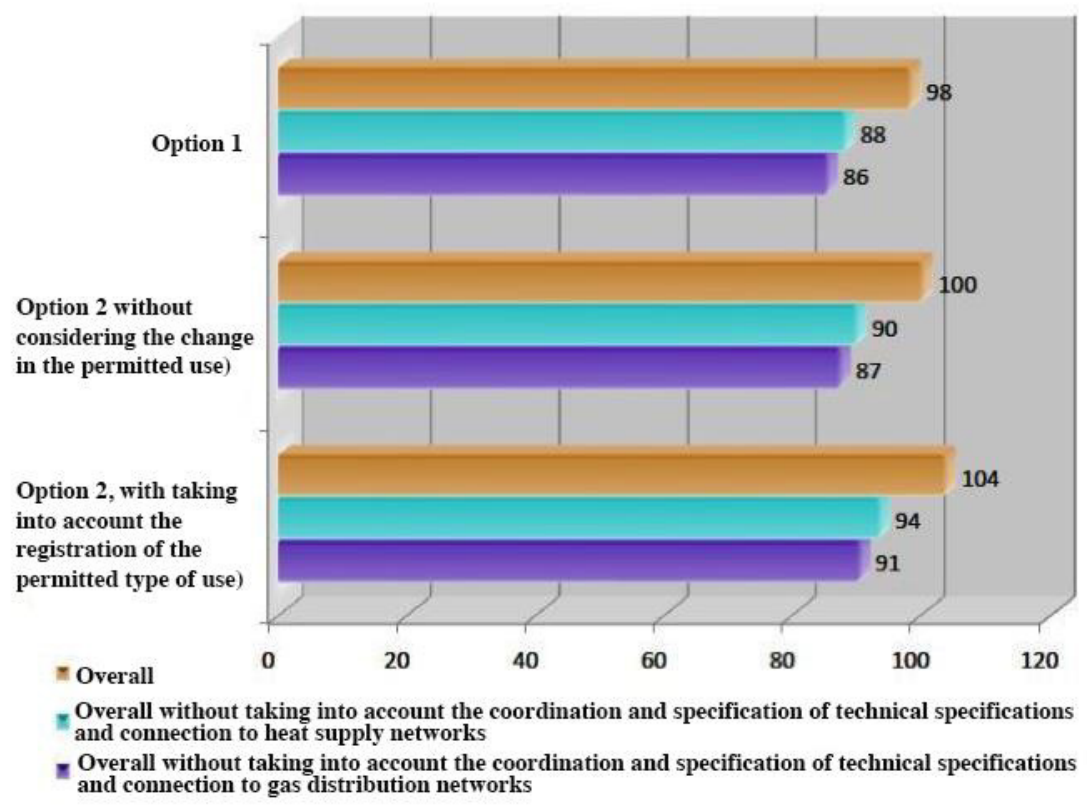

Fig. 1. Aggregate average number of all administrative procedures for the implementation of investment and construction project in the field of high-rise construction.

In general, for the entire period of implementation of the investment and construction project in the field of housing construction, the average number of procedures is approximately the same for all three indicated options for obtaining or having a land plot and ranges from 98 to 104 procedures.

However, the number of administrative procedures is significantly changing depending on the construction phase. Fig. 2 shows the minimum, maximum and average values of the number of administrative procedures at particular stages of the investment project in the field of high-rise construction for the case of the developer obtaining rights to the land plot at the auction. 


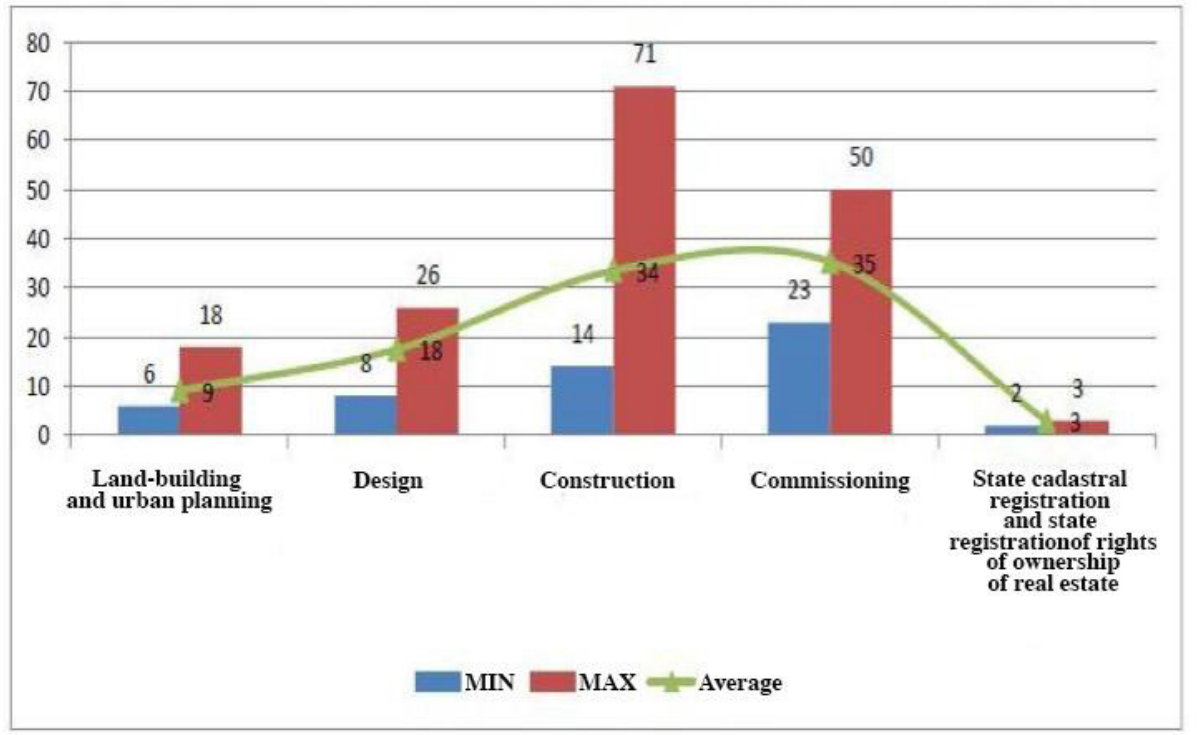

Fig. 1. The average, minimum and maximum number of administrative procedures at particular stages of implementation of the investment and construction project in the field of high-rise construction.

On average, when implementing an investment and construction project in the field of high-rise construction, constructors pass 100 procedures, spending about 3 years and about 25 million rubles [16]. Most of these costs are the costs of connection to the networks of engineering and technical support, including electrical, thermal, gas distribution networks and water supply and sanitation networks.

\section{Results}

Based on the conducted analysis, the following conclusions can be highlighted regarding the number of administrative procedures for the implementation of the investment and construction project in the field of high-rise construction:

- An average developer needs to complete about 100 procedures. The maximum number of procedures reaches 143 in the case when the land plot that the developer has not received at the auction requires a change in the permitted type of use. The minimum number of procedures is 73 and is achieved in the case when the developer receives rights to the land plot at the auction;

- The general list of all possible procedures includes 182 and 180 procedures respectively in the option of obtaining rights to the land plot at the auction and the option of the developer's rights to the land plot obtained for other reasons;

- Most procedures refer to the stage of commissioning the facility (an average of 34 procedures) and the construction phase (an average of 34 procedures);

- There are significant differences between cities in the composition of administrative procedures;

- Of the total list of all possible procedures common to almost all cities (required in $80-100 \%$ of cases) are only about a third of the procedures - 56 procedures in case of obtaining rights to the land plot at auction and 61 in the event the developer has rights to the land plot, received not at auction; 
- The greatest differences in cities are noted in the procedures related to the period before the start of construction (stages of land management and urban planning, as well as design);

- The smallest differences are noted in the procedures related to the period after the completion of construction (the stages of commissioning the facility, as well as state cadastral registration and state registration of property rights for real estate objects).

\section{Discussion}

The study of world (foreign) experience in the implementation of projects in the high-rise construction industry shows [17-22] that excessive administrative barriers lead to a decrease in the efficiency of construction business, significant losses for society. The results of the sub-national study "Doing Business" conducted by the World Bank and the International Finance Corporation [23] showed that in the ranking of countries, according to the criteria for passing permitting procedures in the construction industry, the Russian Federation ranks 115 out of the represented 190 countries, which may indicate a sufficiently high level of administrative barriers. Nowadays in Russia there is a radical transition to the system of self-regulation in the field of urban development, namely, the All-Russian nongovernmental non-profit organization "National Association of Self-Regulating Organizations, based on the membership of persons engaged in construction" (NOSTROY) was established. This organization is actively conducting research in the field of construction of the Institute of Urban Economics [24], work is beginning to translate the service for issuing construction permits into electronic form [25]. This is the most significant reform to reduce administrative barriers in the era of digitalization of the economy, but still there is a lack of comprehensive measures to reduce administrative barriers in the high-rise construction industry. Moreover, this does not allow the construction community to take an active position in addressing the problem of reducing excessive administrative barriers, including issues of monitoring and evaluating the effectiveness of administrative procedures in the implementation of investment and construction projects. However, there are factors that prevent the reduction of administrative barriers in the construction of high-rise buildings:

1. Imperfection of the legislation regulating activities in this industry, for instance, there is no clear transparent list of administrative procedures when the developer passes all phases of the investment and construction project and the lack of detailed, approved regulatory acts that reduce administrative barriers at all stages of the investment- building project.

2. Lack of mechanisms for strict control and measures of responsibility for the implementation of legislative procedures.

3. Lack of consideration of regional peculiarities of construction of high-rise buildings and structures.

4. Practically complete absence of "feedback" and coordinated work of federal and municipal authorities.

5. The absence of a unified policy on pricing in the construction, reconstruction and capital repairs of municipal facilities at the expense of budgetary funds.

6. Lack of well-established cooperation with banks on the restructuring of debt on loans received by construction companies in Russian credit institutions, in the implementation of investment and construction projects.

7. Conflict of interests of state authorities and developers.

8. The complexity of procedures for securing the capital construction site with engineering and technical infrastructure, including electrical, thermal, gas distribution networks and water supply and sanitation networks. 


\section{Conclusions}

Thereby, in order to improve the efficiency of investment and construction projects in the high-rise construction industry, it is necessary to make changes in the legislation to reduce the impact of factors that hinder the reduction of administrative barriers at all stages of project development and implementation, and also provide developers with the opportunity to pass the relevant administrative procedures via digital services.

\section{References}

1. A. Bril, O. Kalinina, I. Ilin, In: MATEC Web of Conferences. EDP Sciences 8010 (2017).

2. Bjulleten' o razvitii konkurencii [Bulletin on the development of competition], (2013), Vypusk 1, URL: http://ac.gov.ru/files/publication/a/509.pdf. (cited: 19.12.2017).

3. A.V. Anisimov, Jekonomika i biznes: teorija i praktika, 2-11 (2016).

4. A.O. Sitnikov, Nauchnyj al'manah, 7-1(33), 52-57 (2017).

5. R. I. Malikov, K. E. Grishin, Vestnik UGUJeS. Nauka, obrazovanie, jekonomika, 4 (6), 55-65 (2013).

6. D.V. Manushin, Aktual'nye problemy jekonomiki i prava, 4 (32), 52-60 (2014).

7. M.V. Podbivalova, Zhurnal pravovyh i jekonomicheskih issledovanij, 4, 264-267 (2013).

8. Portal. Nacional'noe obedinenie stroitelej. NOSTROJ. [Portal. National Association of Builders. NONSTROY] - URL: http://nostroy.ru/department/sektor-reestra/monitoringdeyatelnosti-sro/. (cited: 14.12.2017).

9. Gradostroitel'nyj kodeks Rossijskoj Federacii ot 29.12.2004 g. № 190-FZ [Urban Development Code of the Russian Federation of 29.12.2004 № 190-FZ] ( v red. 31.12.2017. - URL: http://www.consultant.ru/document/cons_doc_LAW_51040/. (cited 10.12.2017).

10. Rasporjazhenie Pravitel'stva RF. № 1336-r [Order of the Government of the Russian Federation № 1336-r] «Ob utverzhdenii plana meroprijatij («dorozhnoj karty») «Sovershenstvovanie pravovogo regulirovanija gradostroitel'noj dejatel'nosti i uluchshenie predprinimatel'skogo klimata v sfere stroitel'stva» ot 29 ijulja $2013 \mathrm{~g}$.

11. Postanovlenie Pravitel'stva RF № 403 [Resolution of the Government of the Russian Federation No. 403] «Ob ischerpyvajushhem perechne procedur v sfere zhilishhnogo stroitel'stva» ot 30.04.2014.

12. Rasporjazhenie Pravitel'stva RF № 1554-r [Order of the Government of the Russian Federation No. 1554-r] «Plan meroprijatij po podgotovke proektov federal'nyh zakonov, aktov Pravitel'stva RF i vedomstvennyh aktov, neobhodimyh dlja otmeny izbytochnyh i (ili) dublirujushhih procedur, a takzhe sovershenstvovanija realizacii procedur, vkljuchennyh $\mathrm{v}$ ischerpyvajushhij perechen', utv. Postanovleniem Pravitel'stva RF ot 30.04.2014 g. № 40313.08.2015 g.») ot 13.08.2015.

13. I.V. Ilin, O.V. Kalinina, A.I. Levina, O.Yu. Iliashenko, In: MATEC Web of Conferences 5028 (2016).

14. N. Kosareva, A. Puzanov, Fast Forward: City Planning in a Hyper Dynamic Age. ISOCARP Review. (2012). 
15. V.V. Gluhov, I.V. Ilin, In: International Conference on Next Generation Wired/Wireless Networking. Springer 509-518 (2014).

16. T.G. Polidi, Voprosy imushhestvennoj politiki, 2(149) (2014).

17. Y. Mahgoub, B. Abbara, Procedia-Social and Behavioral Sciences, 36, 640-649 (2012).

18. A. Collins, S. Watts, M. McAlister, CTBUH 8th World Congress, 175-185 (2008).

19. V. Antoniucci, C. D'Alpaos, G. Marella, International Journal for Housing Science \& Its Applications, 39. - №. 2 (2015).

20. P. De Jong, H. Wamelink, CTBUH 8th World Congress, 3-5 (2008).

21. E. L. Glaeser, B. A. Ward, Journal of Urban Economics, T. 65. №. 3, 265-278 (2009).

22. D. Parker, A. Wood (ed.). The Tall Buildings Reference Book. - Routledge, 512 (2013).

23. Portal Doing Business. Ocenka biznes regulirovanija. [Portal Doing Business. Evaluation of business regulation] - URL: http://russian.doingbusiness.org/rankings. (cited: 20.12.2017).

24. Portal. Institut jekonomiki goroda [Portal. Institute of Urban Economics]. - URL: http://www.urbaneconomics.ru/research. (cited: 22.12.2017).

25. Agentstvo novostej «Stroitel'nyj biznes» [News Agency "Construction business"] URL: http://ancb.ru/news/read/4617. (cited: 27.12.2017). 